is of usual type. Root hairs are absent. The invading hypha forms a sort of appressorium before penetration. It is sometimes developed between the epidermal cells and it is also found directly opposite their outer walls. After invasion of the thick outer cellulose wall, the fungus proceeds through the cell cavity. It then develops in a very characteristic spiral fashion through a radial row of cortical cells 3-4 layers deep. After that it spreads laterally and inwardly for 3-4 layers producing these spirally coiled hyphæ within the cells. Then it ramifies in the cortex, producing intra- and inter-cellular mycelia and developing vesicles and arbuscules. Vesicles differ in shape

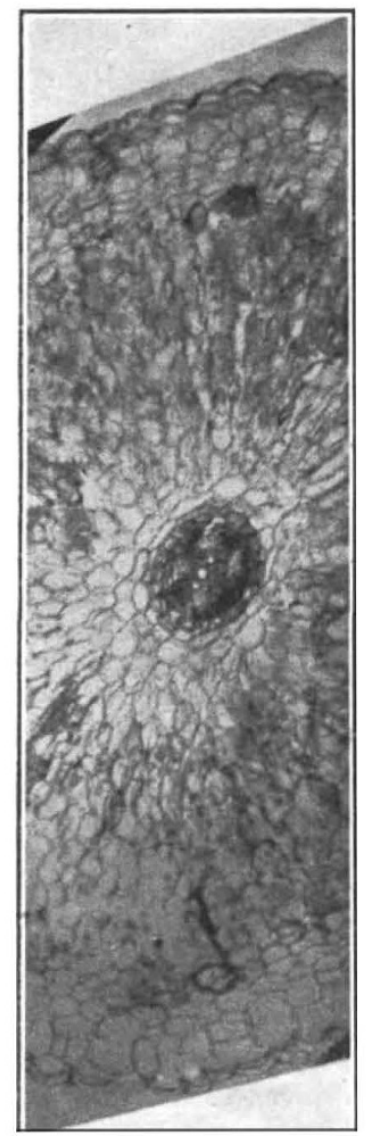

Fig. 2.

Transverse SECTION OF INFECTED ROOT SHOWING DISTRIBUTION OF THE FUNGUS. IN THE TOP PART SPIRALS AND VESICLES ARE SHOWN.

and size and they may be inside the cells or between them. Arbuscules chiefly develop in the mid-cortex and in the deeply seated layers. In good material the whole of the cortical cells and the intercellular spaces, with the exception of the outermost 4-6 layers and the two layers next to the endodermis, are seen to be packed with the fungus.

Cultivation of the fungus and its cytological characters are under investigation.

Younis SABet.

Botany Department,

Faculty of Sciance,

Abbasieh, Cairo.

March 20.

\section{Blind Seed Disease of Ryegrass}

IT is now known that the blind seed disease of ryegrass, associated with low germination, has been present in Great Britain for at least four years. It appears that the true perennials are particularly susceptible and, as these are the more valuable forms, the disease is of considerable economic importance.

This disease of ryegrass was described in New Zealand by $\mathrm{Hyde}^{1,2}$ and by Neill and $\mathrm{Hyde}^{3}$. The causal fungus was associated by these writers with the genus Pullularia, although it does not exhibit spore budding characteristic of that genus. When work was begun on this disease in Britain, a Pullularia form was isolated from seeds which were infected by the blind seed fungus ${ }^{4}$ and, as at that time the paper by Neill and $\mathrm{Hyde}^{3}$ was not available, the two fungi were not clearly distinguished. They are, under certain cultural conditions, very similar and therefore, in view of the original description of the blind seed disease as the 'Pullularia disease', it is desirable to record that, in Britain, the blind seed fungus as well as Pullularia sp. are often present on one and the same ryegrass seed. The exact identity, relative pathogenicity and frequency of occurrence of these fungi are under investigation.

Malcolm Wilson.

M. NoBLE.

E. G. Gray.

Department of Mycology, University of Edinburgh. April 23.

${ }^{1}$ Hyde, E. O. C., N. Zealand J. Agric., 44, 316 (1932).

${ }^{2}$ Hyde, E. O. C., N. Zealand J. Agric., 57, 301 (1938).

${ }^{3}$ Neill, J. C., and Hyde, E. O. C., N. Zealand J. Sci. Tech., 20, 281a (1939).

${ }^{4}$ Noble, M., Ann. App. Biol., 26, 630 (1939).

\section{Humpback Whales off West Australia}

I NOTICE in NATURE of December 16, 1939, an interesting article by G. W. Rayner on the "Preliminary Results of the Marking of Whales by the Discovery Committee". In this article it is stated that a north and south migration of Humpback whales "along the western coast of Australia has been conjectured for some time past". While I am interested to note that Humpback whales marked in the Antarctic have appeared off the north-west Australian coast, I must criticize the use of the word conjectured in the above reference to western Australia.

During the years 1913-15 the movements of the whales on this coast were very carefully watched by the Norwegian whalers, and I had an opportunity on several occasions not only of observing this migration at different points, but also I had access to $\mathrm{log}$ books which indicated fairly clearly the times of appearance of the whales and the direction of migration.

The whaling season off the coast of north-west Australia is very definitely limited by the restriction in the time of occurrence of the breeding humpbacks. The dates of their arrival and departure are well known ; and in my book "Whalemen Adventurers" (Angus and Robertson, Sydney, 1934) I have given a map to illustrate the direction of the west Australian migration so far as could be judged by the data available. I venture to think that this can scarcely be called a mere conjecture. The place whence the 